*aMIS View/Print Document Cover Sheet

This document was retrieved from the Boeing ISEARCH System.

Accession \#: D196069889

Document \#: SD-WM-TP-358

Title/Desc:

TANK 241A102 TANK CHARACTERIZATION PLAN 


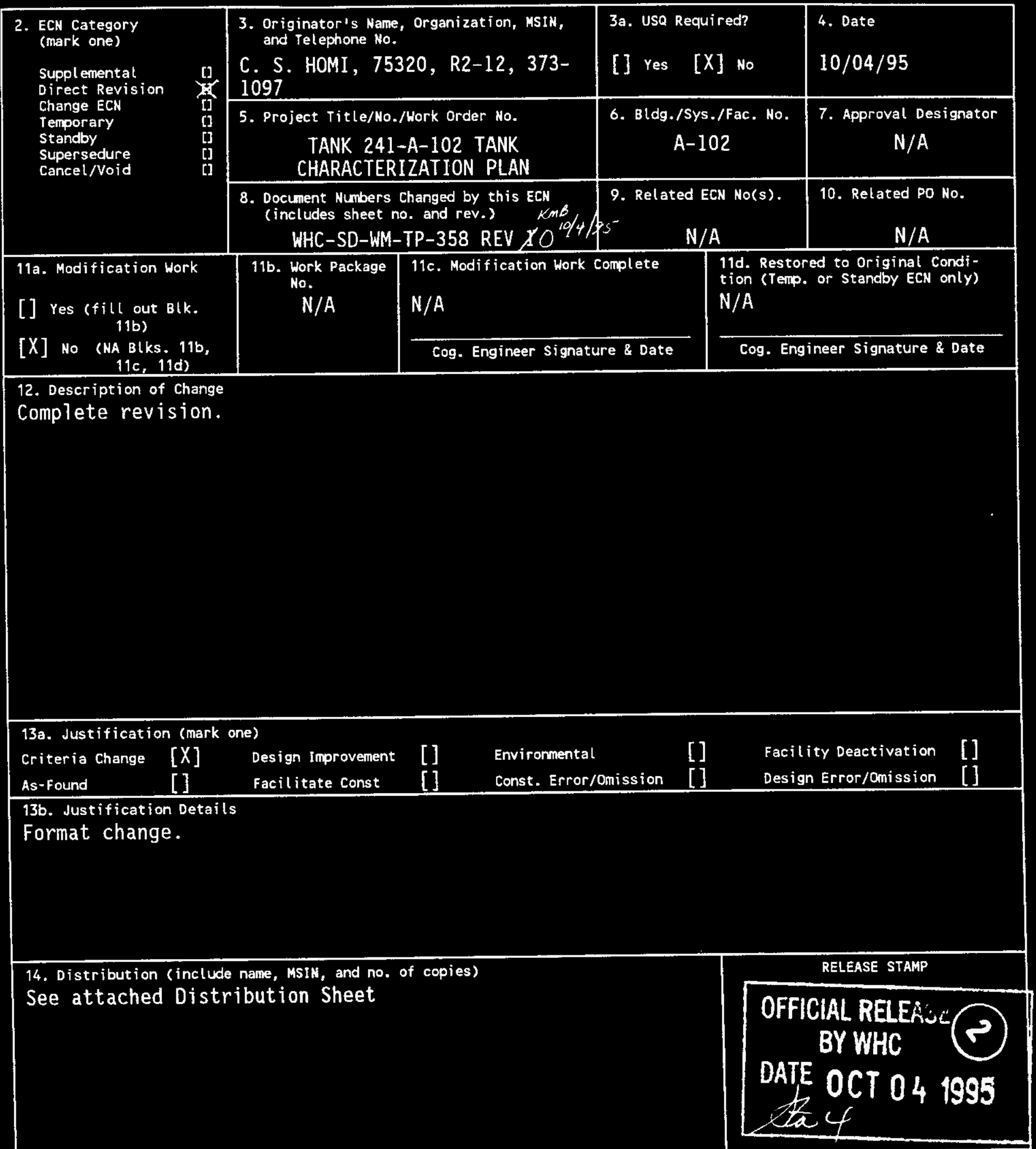




\section{RELEASE AUTHORIZATION}

Document Number: WHC-SD-WM-TP-358, REV 1

Document Title: Tank 241-A-102 Tank Characterization P1an

Release Date: $\quad$ 10/4/95

This document was reviewed following the procedures described in WHC-CM-3-4 and is:

APPROVED FOR PUBLIC RELEASE

WHC Information Release Administration Specialist:
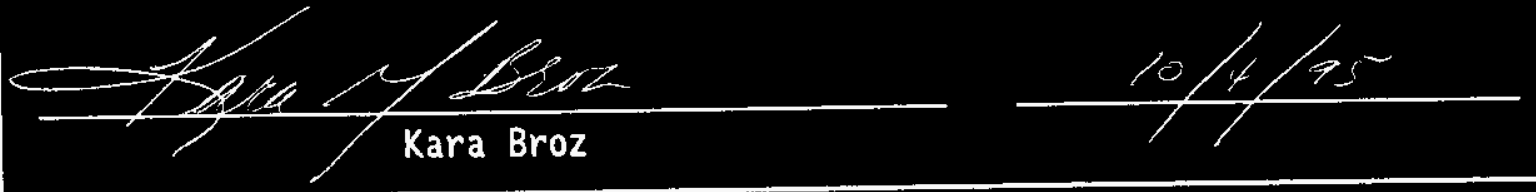

TRADEMARK DISCLAIMER. Reference here in to any specific commercial product, process, or service by trade name, trademark, manufacturer, or otherwise, does not necessarily constitute or imply its endorsement, recommendation, or favoring by the United States Government or any agency thereof or its contractors or subcontractors.

This report has been reproduced from the best available copy. Available in paper copy. Printed in the United States of America. To obtain copies of this report, contact:

Westinghouse Hanford Company - Document Control Services

P.0. Box 1970, Mailstop H6-08, Richland, WA 99352

Telephone: (509) 372-2420; Fax: (509) 376-4989 


\begin{tabular}{|l|l|c|}
\hline $\begin{array}{l}\text { 2. Title } \\
\text { TANK 241-A-102 TANK CHARACTERIZATION PLAN }\end{array}$ & $\begin{array}{l}\text { 3. Number } \\
\text { WHC-SD-NM-TP-358 }\end{array}$ \\
\hline $\begin{array}{l}\text { 5. Key Words } \\
\text { CHARACTERIZATION, GENERAL SAFETY ISSUES, SPECIFIC } \\
\text { SAFETY ISSUES, INFORMATION REQUIREMENTS, PRIORITY }\end{array}$ & 6. Author \\
& Signature \\
& Organization/Charge Code $75320 / N 4 G 6 \mathrm{~A}$ \\
\hline
\end{tabular}

\section{Abstract}

This document is a plan that identifies the information needed to address relevant issues concerning short-term and long-term safe storage and long-term management of Single-Shell Tank (SST) 241-A-102. 


\section{RECORD OF REVISION}

(2) Title

TANK 241-A-102 TANK CHARACTERIZATION PLAN

CHANGE CONTROL RECORD

\begin{tabular}{|c|c|c|c|}
\hline \multirow{2}{*}{ (3) Revision } & \multirow{2}{*}{ (4) Description of Change - Replace, Add, and Delete Pages } & \multicolumn{2}{|c|}{ Authorized for Release } \\
\hline & & (5) Cog. Engr. & (6) Cog. Mgr. \\
\hline 0 & $\begin{array}{l}\text { (7) WHC-SD-WM-TP-358 REV. 0, EDT } 610042 \text {, } \\
\text { May 16, } 1995\end{array}$ & & \\
\hline RS 1 & Complete revision to new format, ECN 625720 & QPDn. & Shet $10 / 4 / 9$ s \\
\hline & & & \\
\hline & & & \\
\hline & & & \\
\hline & & & \\
\hline & & & \\
\hline & & & \\
\hline & & & \\
\hline & & & \\
\hline & & & \\
\hline & & & \\
\hline & & & \\
\hline & & & \\
\hline & & & \\
\hline & & & \\
\hline & & & \\
\hline & & & \\
\hline & & & \\
\hline & & & \\
\hline & & & \\
\hline & & & \\
\hline & & & \\
\hline & & & \\
\hline & & & \\
\hline & & & \\
\hline & & & \\
\hline & & & \\
\hline
\end{tabular}




\title{
Tank 241-A-102 \\ Tank Characterization Plan
}

\author{
C. S. Homi \\ Westinghouse Banford Company
}

Date Published

October 1995

Prepared for the U.S. Department of Energy Office of Environmental Restoration and Waste Management

$\begin{array}{ll}\text { Westinghouse } & \text { P.O Box } 1970 \\ \text { Hanford Company } & \text { Fichland, Washington }\end{array}$

Management and Operations Contractor for the

U.S. Department of Eneroy under Contract DE-ACO6.87fLL10930 


\section{TABLE OF CONTENTS}

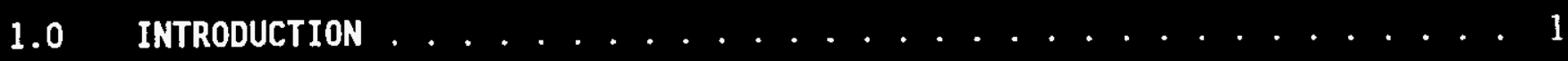

2.0 PROGRAM ELEMENTS REQUIRING INFORMATION FOR 241-A-102 ........ 2

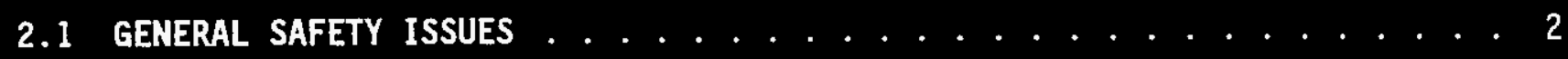

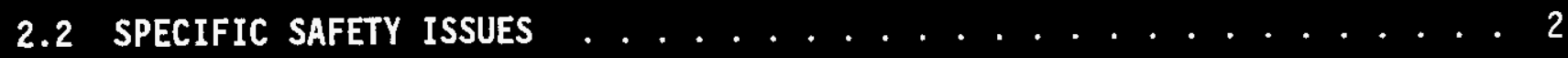

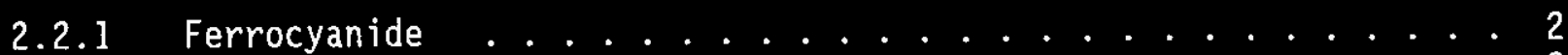

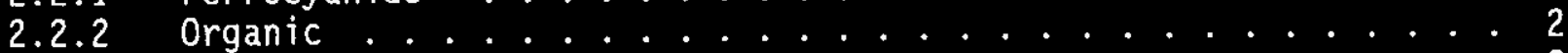

2.2 .3 High Heat ................. 2

2.2 .4 Flammable Gas ................. 2

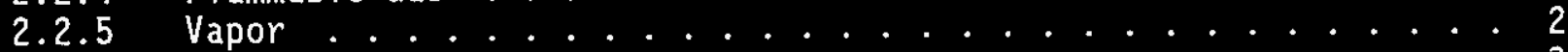

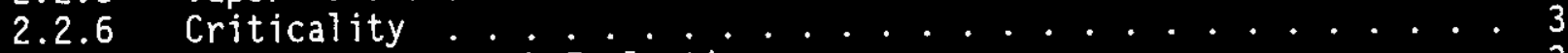

2.2.7 Screening Approach Evaluation ............ 3

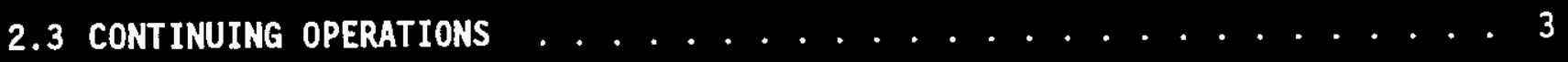

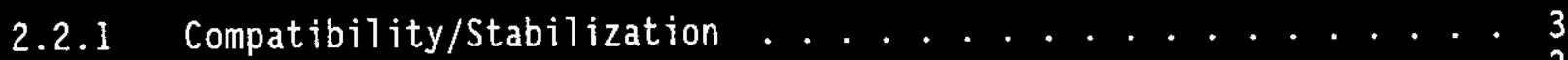

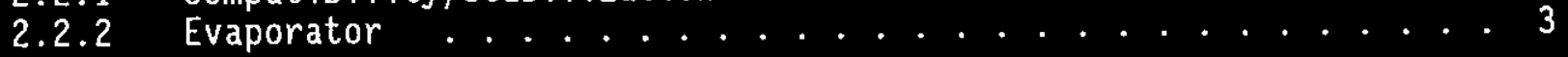

2.4 DOUBLE-SHELL TANK WASTE ANALYSIS PLAN ............ 3

2.5 DISPOSAL . . . . . . . . . . . . . . . 3

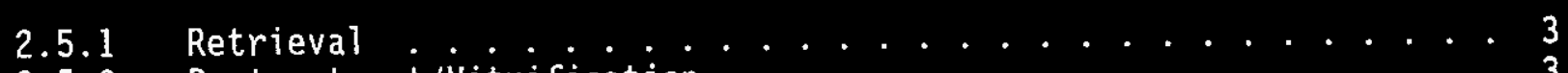

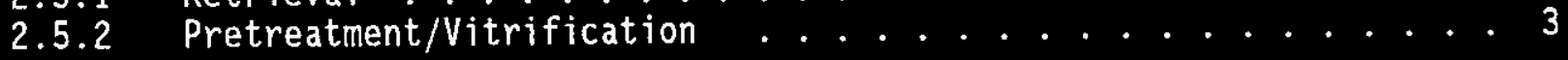

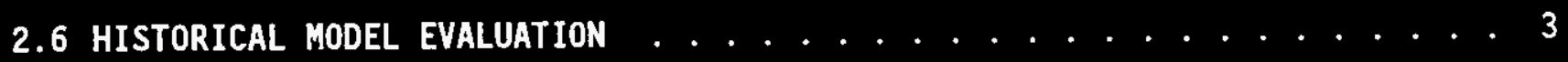

3.0 HOW INFORMATION WILL BE OBTAINED ................ 4

4.0 PRIORITY OF INFORMATION REQUIRENENTS ............... 5

5.0 WHEN INFORMATION IS NEEDED ................. 5

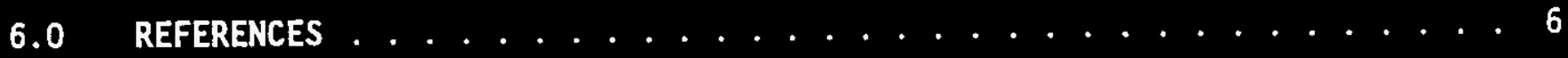

\section{LIST OF TABLES}

Table 4-1: Integrated DQO Requirements ............ 5 
WHC-SD-WM-TP-358, REV 1

\section{LIST OF ABBREVIATIONS}

$\begin{array}{ll}\text { A-102 } & \text { Tank 241-A-102 } \\ \text { DQO } & \text { Data Quality Objective } \\ \text { HTCE } & \text { Historical Tank Content Estimate } \\ \text { DSSF } & \text { Double She11 Slurry Feed } \\ \text { NCPLX } & \text { Non-complexed } \\ \text { SST } & \text { Single-Shel1 Tank } \\ \text { SUMMA } & \text { Trademark of Molectrics, Inc. } \\ \text { TCP } & \text { Tank Characterization Plan } \\ \text { TOC } & \text { Total Organic Carbon } \\ \text { USQ } & \text { Unreviewed Safety Question } \\ \text { WHC } & \text { Westinghouse Hanford Company }\end{array}$




\section{WHC-SD-WM-TP-358, REV 1}

\subsection{INTRODUCTION}

This Tank Characterization Plan (TCP) identifies the information needed to address relevant issues concerning short-term and long-term safe storage and long-term management of Single-She11 Tank 241-A-102 (A-102). It should be understood that the various needs and issues surrounding tank $A-102$ are evolving as new information about the tank is uncovered. As a result of this progression, this Tank Characterization Plan addresses only the issues that, to this date, have been identified. It is expected that deviations from this plan may occur as additional issues or needs arise which impact the management of SST A-102. As necessary, this Tank Characterization Plan will be revised to reflect those changes or deviations.

Tank A-102 was constructed between 1954 and 1955 and was put into service in 1956. Initially tank A-102 received PUREX high level waste and PUREX organic wash waste from the first quarter of 1956 until the third quarter of 1961 and the third quarter of 1963 respectively. During the second quarter of 1960, the tank received PUREX low level waste. The tank received wastewater from the third quarter of 1960 until the first quarter of 1976. The tank was sluiced for strontium and cesium recovery in 1964. The tank received and contained PUREX sludge supernatant waste from the fourth quarter of 1970 until the fourth quarter of 1972. The tank was sluiced, to reduce the sludge heel for saltcake storage, from the fourth quarter of 1972 until the February 1974. The tank received high level B plant waste from the third quarter of 1974 until the first quarter of 1976. Also, from the third quarter of 1974 until the second quarter of 1975, A-102 received strontium recovery waste. Again, the tank was sluiced, during the first two quarters of 1976, to prepare it for saltcake waste storage. From this point until the first quarter of 1978, A-102 received evaporator feed. Non-complexed waste was sent to A-102 the second and third quarters of 1978, the fourth quarter of 1979 and the second and third quarters of 1980. Also, A-102 received complexed waste, from B Plant, from the first through the third quarters of 1979. Presently, the tank waste is classified as DSSF. This tank currently contains a total waste volume of 155 $\mathrm{kL}$ (41 kgal), which is equivalent to 37.9 centimeters ( 14.9 inches) of waste as measured from the baseline of the tank. The waste is comprised of $15 \mathrm{~kL}$ (4 kgal) of supernatant; $83 \mathrm{~kL}(22 \mathrm{kgal})$ of saltcake and $57 \mathrm{~kL}$ (15 kgal) of sludge with no pumpable liquid remaining (Brevick 1994a).

The tank was declared an inactive in November 1980 . Tank A-102 is actively ventilated and was interim stabilized in August 1989 with intrusion prevention completed in 1982. The last photo was taken on July 20, 1989. The 1989 photographic montage indicates a thin gray to saltcake surface layer that is "cracked" in which supernate can be seen (Brevick 1994b). The last solids volume update was obtained on July 27, 1989 (Hanlon 1995).

Waste sample analyses were conducted on A-102 waste samples between May 1963 and May 1989. In December 1980, two waste samples were obtained from different levels within A-102. The results of the analyses conducted on the samples indicated that the deep sample contained solids measured to be 15 wt\% while the shallow sample contained solids at $9 \mathrm{wt} \%$. The solids were primarily sodium nitrate. in 1986 four samples were obtained and analyzed. These samples varied in color and texture. The most recent sample analysis was conducted in May 1989 on a sample of A-102 supernate. From this analysis it was found that A-102 contained a TOC content of $12.4 \mathrm{~g} / 1$. 
This tank is not on a Watch List. Near-term sampling and analys is activities are focused on either verification of the non-watchlist tank status, identification of any new safety issues or changing the non-Watch List status. Should any safety issues be identified additional analysis will occur consistent with the identified issue.

In addition to the resolution of the safety issues, it is intended that all tank waste will be subject to pretreatment and retrieval to prepare for final storage or disposal. Presently, these long-range plans have yet to be fully identified and are, therefore, not included in this document.

\subsection{PROGRAM ELEMENTS REQUIRING INFORMATION FOR TANK 241-A-102}

This section identifies the various program elements, and identifies which of these programs require characterization data from tank A-102.

\subsection{GENERAL SAFETY ISSUES}

The Tank Safety Screening Data Quality Objective (Redus 1995) describes the sampling and analytical requirements that are used to screen waste tanks for unidentified safety issues. The primary analytical requirements for the safety screening of a tank are energetics, total alpha activity, moisture content, and flammable gas concentration.

\subsection{SPECIFIC SAFETY ISSUES}

\subsubsection{Ferrocyanide}

This tank is not on the Ferrocyanide Watch List and; therefore, no information needs are currently identified for this program element.

\subsubsection{Organic}

This tank is not on the Organics Watch List, but recent work by the Organic Safety Program revealed a question regarding organic complexant salts. A potential problem with regard to the complexed salts exists if all the drainable liquid is pumped from the tank (Webb et al 1995). Sampling and analys is requirements must be performed as per Data Quality Objective to Support Resolution of the Organic Fuel Rich Tank Safety Issue (Babad et al 1994b). The analyses employed will determine the TOC, presence of a free organic liquid phase, moisture content and tank temperature.

\subsubsection{High Heat}

This tank is not on the High Heat Watch List and; therefore, no information needs are currently identified for this program element.

\subsubsection{Flammable Gas}

This tank is not on the Flammable Gas Watch List and; therefore, no information needs are currently identified for this program element.

\subsubsection{Vapor}

The tanks currently scheduled to be vapor sampled may be classified into four categories: (1) those tanks which are to be rotary mode core sampled (as a consequence of the rotary sampling system); (2) tanks on the Organic or Ferrocyanide Watch Lists; 
(3) tanks in C farm; and (4) tank BX-104, due to vapor exposure. Since tank A-102 is NOT categorized in one of the above four groups, vapor sampling is not required for this tank.

\subsubsection{Criticality}

No information separate from that for the general safety issue of tank A-102 are currently identified for this program element. However, if the general safety screening of tank A-102 identifies a potential criticality concern, analyses for fissile materials and neutron absorbers and poisons will be performed as identified in the safety screening data quality objective.

\subsubsection{Screening Approach Evaluation}

The safety screening approach is currently under review. Information is required from key tanks to determine if a revised approach to screening may be adopted, as proposed in Meacham, 1995.

\subsection{CONTINUING OPERATIONS}

\subsubsection{Compatibility/Stabilization}

No information needs are currently identified for this program element.

\subsubsection{Evaporator}

No information needs are currently identified for this program element.

\subsection{DOUBLE-SHELL TANK WASTE ANALYSIS PLAN}

No information needs are currently identified for this program element, although work to identify these needs is in progress and expected to be completed in fiscal year 1995.

\subsection{DISPOSAL}

\subsubsection{Retrieval}

Current retrieval needs (Bloom 1995) do not call for test samples to be taken from tank A-102.

\subsubsection{Pretreatment/Vitrification}

Tank A-102 has not been identified as a bounding tank for pretreatment/disposal process development (Kupfer 1995).

\subsection{HISTORICAL MODEL EVALUATION}

Bounding tanks and data requirements for historical model evaluations are found in DQ0 Historical Model Evaluation Data Requirements (Simpson 1995). Tank A-102 has not been identified as a primary bounding tank for any waste type. 


\subsection{HOW INFORMATION WILL BE OBTAINED}

The safety screening $D Q 0$ requires that a vertical profile of the tank waste be obtained from at least two widely spaced risers. This vertical profile may be obtained using core, auger (for shallow tanks), or grab samples. Only an auger sampling event is scheduled and required. The auger sampling type has been chosen over other sampling modes due to both the depth of the tank (A-102 is a shallow tank making rotary core sampling unnecessary) and the fact that the surface of tank A-102 is comprised of saltcake.

The best current estimate of the water content in tank A-102 solids, as determined from the process records, is 45.4\%; based on the HTCE (Brevick et a1). Estimated (Toth et al 1995) water content in tank A-102 saltcake and sludge is $43.1 \%$ and $39.5 \%$ respectively (generated from a model based on sample data from similar tanks). If the variance of water in tanks already sampled and a statistical power curve is used then a minimum of two cores are needed to demonstrate a water content above $17 \%$ at $95 \%$ confidence. Should the measured mean be lower than anticipated or the measured variance higher, additional samples may be required. The TOC contained within the saltcake and sludge is estimated (Toth et al 1995) to be $0.6 \%$ (wet basis) for both, which is significantly lower than the level of concern. Two core samples will be requested for this tank and this should meet the requirements for the above parameters.

The best current information indicates that 3 risers are available for sampling of tank $A-102,4$ inch $(10.2 \mathrm{~cm})$ riser $R 5,8$ inch $(20.3 \mathrm{~cm})$ riser $R 2$ and 12 inch $(30.5 \mathrm{~cm})$ riser R19. It is recommended that these risers be chosen because, they are risers that are separated radially to the maximum extent possible and; therefore, will provide a larger amount of data about the vertical and horizontal waste layers with in the tank. Initial information will be taken from these 3 risers and assessed to determine if more samples are required. One additional riser is available but, equipment will have to be removed from each individual riser to utilize this riser for sampling. Alternate sampling methods, installation of a riser or removal of equipment from risers presently considered unavailable, are possible future options. 
WHC-SD-WM-TP-358, REV 1

\subsection{PRIORITY OF INFORHATION REQUIREMENTS}

Vapor sampling is scheduled for October 1995. Auger sampling was completed in June 1995 (Stanton 1995).

Table 4-1: Integrated DQO Requirements

\begin{tabular}{|l|l|l|l|}
\hline $\begin{array}{c}\text { Sampling } \\
\text { Event }\end{array}$ & \multicolumn{1}{|c|}{ Applicable DQO } & Sampling Requirements & Analytical Requirements \\
\hline Vapor & $\begin{array}{l}\text {-Health \& Safety Vapor } \\
\text { Issue Resolution DQO }\end{array}$ & $\begin{array}{l}3 \text { SUMMA canisters } \\
6 \text { Triple Sorbent Traps } \\
8 \text { Sorbent Trap Systems }\end{array}$ & $\begin{array}{l}\text { Gas Flammability } \\
\text { Gas Toxicity } \\
\text {-Organic Vapors } \\
\text {-Permanent Gases }\end{array}$ \\
\hline $\begin{array}{l}\text { Auger } \\
\text { Sampling }\end{array}$ & $\begin{array}{l}\text {-Safety Screening DQ0 } \\
\text {-Organic DQ0 }\end{array}$ & $\begin{array}{l}\text { Core samples from 2 } \\
\text { risers separated } \\
\text { radially to the maximum } \\
\text { extent possible }\end{array}$ & $\begin{array}{l}\text { Energetics, Moisture, } \\
\text { Orgal Alpha, Total } \\
\text { Cations, Anions, } \\
\text { Radionuclides }\end{array}$ \\
\hline
\end{tabular}

\subsection{WHEN INFORHATION IS NEEDED}

Data are required for Tank A-102 during FY 1996 for safety screening and to prepare a Tank Characterization Report. 


\section{WHC-SD-WM-TP-358, REV 1}

\subsection{REFERENCES}

Babad, H, K. S. Redus, and J. W. Hunt, 1995a, Tank Safety Screening Data Quality Objective, WHC-SD-WM-SP-004, Rev 1, Westinghouse Hanford Company, Richland, Washington.

Babad, H., S. M. Blacker, and K. S. Redus, 1995b, Data Quality Objective to Support Resolution of the Organic Fuel Rich Tank Safety Issue, WHC-SD-WM-DQ0-006, Rev. 1, Westinghouse Hanford Company, Richland, Washington.

Bloom, G. R., and Q. H. Nguyen, 1995, Characterization Data Needs for Development, Design, and Operation of Retrieval Equipment Developed Through the Data Quality Objective Process, WHC-SD-WM-DQ0-008, Rev. 0, Westinghouse Hanford Company, Richland, Washington.

Brevick, C. H., 1994a, Historical Tank Content Estimate for the Northeast Quadrant of the Hanford 200 East Areas, WHC-SD-WM-ER-349, Rev. OA, ICF Kaiser Hanford Company, Richland, Washington.

Brevick, C. H., 1994b, Supporting Document for the Historical Tank Content Estimate for BX Tank Farm, WHC-SD-WM-ER-311, Rev. 0, ICF Kaiser Hanford Company, Richland, Washington.

Brown, T. M., S. J. Eberlein, D. A. Dodd, T. J. Kunthara, B. C. Simpson, and N. W. Kirch, Tank Waste Characterization Plan and Basis, 1995, WHC-SD-WM-TA-164, Rev 0, Westinghouse Hanford Company, Richland, Washington.

Han1on, B.M., 1995, Waste Tank Summary for Month Ending May, 1995, WHC-EP-0182-82, Westinghouse Hanford Company, Richland, Washington.

Homi, C. S., and S. J. Eberlein, 1995, Fiscal Year 1996 Tank Waste Remediation System Tank Waste Analys is Plan, WHC-SD-WM-PLN-101, Rev 0, Westinghouse Hanford Company, Richland, Washington

Kupfer, M. J., W. W. Schultz, and J. T. Slankas, 1995, Strategy for Sampling Hanford Site Tank Wastes for Development of Disposal Technology, WHC-SD-WM-TA-154, Rev. 1 , Westinghouse Hanford Company, Richland, Washington.

Meacham, J. E., R. J. Cash, B. A. Pulsipher, and G. Chen, 1995, Data Requirements for the Ferrocyanide Safety Issue Developed through the Data Quality Objectives Process, WHC-SD-WM-DQ0-007, Rev. 1, Westinghouse Hanford Company, Richland, Washington.

Osborne, J.W., J.L. Huckaby, E.R. Hewitt, C.M. Anderson, D.D. Mahlum, B.A. Pulsipher, and J.Y. Young, 1995, Data Quality Objectives for Generic In-Tank Health and Safety Vapor Issue Resolution, WHC-SD-WM-DQ0-002, Rev. 1, Westinghouse Hanford Company, Richland, Washington.

Price, D. N., 1994, Rotary Core Vapor Sampling Data Quality Objective, WHC-SD-WM-SP-003, Rev. 0, Westinghouse Hanford Company, Richland, Washington.

Simpson, B. C., and D. J. McCain, 1995, Historical Model Evaluation Data Requirements, WHC-SD-WM-DQO-018, Rev. 0, Westinghouse Hanford Company, Richland, Washington. 
Stanton, G. A., 1995, Baseline Sampling Schedule, Revision 4.4, (internal memo 74320-95-04, to distribution, March 24), Westinghouse Hanford Company, Richland, Washington.

Toth, J. J., P. G. Heasler, M. E. Lerchen, J. G. Hill, and P. D. Whitney, 1995, Analys is of Organic Carbon and Moisture in Hanford Single-Shell Tank Waste, PNL10360, Pacific Northwest Laboratory, Richland, Washington.

Webb, A. G., J. L. Stewart, D. A. Turner, M. G. Plys, B. Malinovic, J. M. Grigsby, D. M. Camaioni, P. G. Heasler, W. D. Samuels, and J. J. Toth, 1995, Preliminary Safety Criteria for Organic Watch List Tanks at the Hanford Site, WHC-SD-SARR033, Rev. 0, Draft, Westinghouse Hanford Company, Richland, Washington. 